\title{
'You've got mail': a film workshop
}

\author{
Ali Nihat Eken
}

This article looks at using feature films in the English language classroom. A specially designed course is described, and an outline description given of a film workshop conducted by students of the Bilkent University School of Applied Language. The effects of the workshop on students are discussed, and suggestions made for ways to use feature films in the English language classroom. The article indicates that studying feature films in such a context helps students in several ways: as they develop a wider understanding of the art offilm-making, they gain critical awareness of how media texts are constructed and how they can be deconstructed; they improve their English in a new context through speaking, writing, reading, and listening; they gain confidence in speaking in front of an audience, and they improve their presentation skills.

Introduction

'American Beauty deserves all the Oscars it has won, don't you think so?'; 'The final scene in The Fight Club is shocking'; 'Shall we go to the cinema to see The Sixth Sense tonight? Everybody says that it is full of surprises ...'. There is no doubt that films are a popular topic of our daily conversations, and even if we don't all talk about films, we very often hear others speak about them. For example, Tom Brook, who reports for B BC World's Talking Movies, and Laurin Sydney reporting for CNN's Showbiz Today. Furthermore, there are lots of newspapers and magazines with carefully designed color sections, and supplements on films or blockbusters. Film stars can appear anywhere unexpectedly: not only in many youngsters' dreams, but also on the walls of their bedrooms, or on the T-shirts they wear. Films thus provide a rich and popular context for people to talk together and exchange ideas.

An examination of the relevant work in ELT and Media Studies indicates that films, along with other authentic media forms and video materials, are used for different purposes, and that when chosen and exploited in a principled manner, they have an important role in modern English language teaching (Allan I985, Tomalin I986, Geddes and Sturtridge I988, Stempleski and Tomalin I990, Hill I99I, Rivers I994, and Baddock 1996). They 'help bring the outside world into the classroom' (Tomalin I986: 9), and 'present realistic slices of life' (Allan I985: 48), motivate students, encourage them to communicate with each other more eagerly, and help them to learn from each other (Hill ibid., Stempleski and Tomalin ibid.). Through films students also learn about 
'non-verbal communication, the types of exclamation and filling expressions that are used, how people initiate and sustain a conversational exchange and how they negotiate meaning' (Rivers I994: II). They also learn about cross-cultural comparisons (Stempleski and Tomalin I990). Films are also employed as valuable teaching aids in sharpening students' powers of observation, developing their skills, and the habits of perceptive watching. By looking at a film students and viewers engage with it intellectually and creatively. They learn how to think along numerous dimensions rather than one, and thus notice more significant detail, such as the lighting, composition, camera angles, and camera distances from the subject (Boggs I996, Phillips 1999). In other words, by thinking along different dimensions, the viewers or the students can understand more meanings, and they can 'participate actively in an exciting quest rather than respond passively to the surface details' (Boggs 1996: xii-xiv).

Films are also very useful resources to help increase students' media literacy. Hart (I99I) and Teasley and Wilder (I997) believe that in mediasaturated societies, where students increasingly interact with different forms of media, such as the Internet and CD-ROMs, the thoughtful use of film is a good way to start making students media literate. By integrating media literacy activities into our lessons 'students can be helped to deconstruct and analyze media texts, think critically about them, and thus gain critical autonomy in the interpretation of media texts they encounter in their daily lives' (Eken 2000: 3).

Using films as supplementary material is by far the most fruitful role for the medium as a result of the recent shift from the structure/grammarbased syllabus towards process/task-based ones, which favors the bringing-in of film scenes as bases for different tasks and activities (Baddock 1996). However, this study regards film as a main subject to be taught via English in the school curriculum. Therefore, it departs from the practice that only uses films to introduce new issues or language structures, or as motivational tools or fillers for Friday afternoons.

The study

I designed a I4-week undergraduate course on 'Media Studies' for students at the School of Applied Languages at Bilkent University. The course aimed to create a new context for students in our school through which they could not only practise their English, but also develop their ability to think critically by exploring and analyzing how media texts (films, videos, newspaper articles, etc.) are constructed. The first phase of the course lasted for Io weeks, and focused mainly on popular films and their analysis, with the aim of helping students to deconstruct films and analyze them. Our discussions and analysis focused on areas such as narrative, characters, setting, theme, signs, costumes, and music. Students were also encouraged to apply their skills to the interpretation of other media texts, e.g. television and radio programs, newspapers, and magazines. The second phase of the course, which lasted four weeks, depended heavily on students' work: they prepared and carried out a film workshop in groups, applying the knowledge and skills they had gained in the first phase. 
A framework for analyzing films
For the workshop I provided my students with a framework I adapted from Teasley and Wilder (I997) since it provided a rich source for examining different aspects of a film (see below). An examination of the work of Phillips (I999), Branston and Stafford (I996), and Baddock (I996) also supported the need for such a framework, and helped me to categorize different aspects of a film. Thus, my aim was not only to enhance students' language skills but also to help improve their critical thinking skills. I adapted the Teasley and Wilder framework by focusing on what I considered to be the main aspects of a film, and leaving out other aspects I felt were too technical, or which required almost expert knowledge for analysis of films (e.g. duration of shots, continuity editing, use of lenses). I also added a language component to the framework to enhance my students' knowledge of vocabulary, and to improve their skills in listening, speaking, reading, and writing.

\section{A Literary aspects of a film}

Narrative: the story, the storyline, and what the storyline is based on: binary oppositions; disruption of an equilibrium, and how a new equilibrium sets in.

Characters: heroes, villains, helpers, main characters, and supporting characters; how characters function, and how they contribute to our understanding of the story.

Setting: physical environment in which filming occurs, indoor or outdoor setting, their significance.

Theme: general statement about the subject.

Signs: anything perceptible that has significance beyond its usual function or meaning; an object, a sound, a person, an act, a color, etc.

Genre: romance, comedy, suspense, a combination of different genres.

\section{B Dramatic aspects of a film}

Acting: the performance of actors, whether it is convincing or not.

Costumes: formal clothes, informal clothes, their color, and their contribution to the film.

Make-up: style, color, whether it is exaggerated or plain, the effects it creates, colors, etc.

\section{Cinematic aspects of a film}

Camera angles, movements and positions: low-camera angle, high camera angle, close-up, extreme close-up, tilted camera, etc., and how they affect our understanding.

Sound and vision: sound effects, soundtrack music, visual effects, etc.

Lighting: illumination in a scene. 


\section{Language work}

Vocabulary: Internet-related vocabulary, books, and bookstores-related vocabulary.

Skills: integrated skills with a greater focus on speaking and writing.

The film workshop the students conducted was on You've Got Mail (I998), a film directed by Nora Ephron. Since in the first phase of the course students gained familiarity with the literary, dramatic, and cinematic aspects of a visual media text through the analysis of films, pop music videos, television commercials, and newspapers and magazines, they had a good understanding of the aspects specified in the framework above when they started to work on their workshop. Below is a detailed outline of what the students did in the workshop, which consisted of a total of I2 hours (3 hours a week).

Week 1

Week 2

Weeks 3 and 4
I discussed the aims of the workshop with all of the students, highlighting critical thinking and improving language skills as the two main aims. I introduced the framework above, encouraged discussion of the different aspects presented, and explained how students would make use of the framework in their workshop. I then divided the class into four groups, and assigned each group one aspect of the film: literary aspects, dramatic aspects, cinematic aspects, and language work. I then told each group to create activities and tasks that they could use while examining the film with the rest of the class for the purposes mentioned above. Each group watched and worked on the film and their assigned focus in four different video rooms. This meant that they could have the control of the video recorder, pause it, discuss points, and take notes when necessary.

While students continued to work on the films in the different video rooms, I visited each group for tutorials. This helped me to see how each group was progressing. It also helped students to receive guidance from me when necessary. We exchanged ideas about how to conduct the workshop, what ideas they had for attracting the attention of their audience (i.e. the rest of the class), and talked about each item specified in the framework.

The work students carried out in the first phase of the course helped them to structure their workshop carefully. They also referred to books on film studies that were available at the university library, and discussed how they could make use of them, and apply the ideas they found in these books.

In the third and fourth weeks, the groups presented their workshop in the classroom. As mentioned earlier, each group examined the film from a different aspect by involving their audience in the activities they had designed. What follows is a description of some of the activities that groups came up with, and used in their workshop: 


\section{Activity I: What's in the film box?}

Focus: Literary aspects of a film

Students put some objects into the box, gave the box to someone in the audience, and asked him or her to randomly take an object out of the box, and then to think of how the object relates to the characters, theme, setting, or signs or symbols in the film. After the first student commented on the object, the other students offered other interpretations. Then the first student passed the box to another student, who picked out another object from the box, and commented on it in a similar fashion. This activity generated a lot of discussion and interpretation, and reinforced the students' understanding of the literary aspects of a film. Among the objects in the box were a handkerchief (possibly belonging to Kathleen's mother), a toy computer (possibly related to Kathleen and Joe's computer), and an old record (possibly related to a love song in the film).

\section{Activity 2: 'Read my wall poster'}

Focus : Literary aspects of a film

Students designed colorful posters to analyze the narrative, characters, and themes in the film. They made use of pictures and captions in the posters to encourage discussion of the different literary aspects of the film, such as the binary oppositions in the film, e.g. a small bookshop (The Shop Around the Corner) vs. a giant bookshop (The Fox); new technology (the computer/email) vs. old technology (Kathleen's partner's typewriter).

\section{Activity 3: 'Memorable quotes' Focus: Literary aspects of a film}

Students either searched through the Internet or transcribed dialogues from the film to focus on some interesting quotes. They then wrote them on an OHT, and asked their audience to identify which characters these quotes belonged to. The task generated some interesting ideas, with students justifying and supporting their views.

\section{Activity 4: 'Look at my clothes and make-up’ Focus: Dramatic aspects of a film}

One of the groups took photos of the group members wearing different clothes and make-up: a cowboy, a punk, etc. They showed these photos and asked their audience to discuss what clothes and make-up could signify about people. They then showed movie stills or video extracts from You've Got Mail to encourage discussion about the costumes and make-up in the film. 
Activity 5: 'Contrasting tunes'

Focus: Cinematic aspects of a film

In this activity, students chose a scene from the film and showed it to the class with the sound off. While the audience watched the video, they played the tape-recorder to use a piece of music which contrasted with the underscore. They encouraged a discussion on whether or not the music fitted in. After the discussion, the group showed the video again, this time with the original underscore. This activity increased students' awareness of how music is used in films.

\section{Activity 6: 'My first film'} Focus: Cinematic aspects of a film

One of the groups produced their own short-length suspense film in order to focus on camera angles, positions, and movements. This drew a lot of interest and attention on the part of their audience, who were highly motivated to take part in the activities. The group first got the audience to discuss cinematic aspects of their film (e.g. camera angles, movements, sound, lighting) and then did the same by using extracts from You've Got Mail.

\section{Activity 7: 'If we were in their shoes ...'}

\section{Focus: Literary aspects of a film}

One of the groups used a role-play to discuss to what extent You've Got Mail is realistic as a romantic comedy. The group asked for two volunteers, and provided them with a situation similar to the one in the film. The volunteers were free to improvise in any way they wanted. For example, there was a scene in which Kathleen (Meg Ryan) and Frank (Greg Kinnear) broke up all of a sudden, apparently without having a quarrel. The volunteers acted out a similar situation, but their reaction was different from that of Kathleen and Frank: they had a big quarrel. This led to an interesting discussion on how realistic romantic comedies are, and how realistic they should be.

\section{Activity 8: 'Reacting to different reviews' Focuss: Language work}

One of the groups distributed extracts from two different reviews of You've Got Mail: one praising the film, and the other criticizing it bitterly. The group asked the audience to read the extracts carefully, and to analyze the language used by underlining expressions which revealed positive and negative attitudes towards the film. Students were then asked to compare their analyses in pairs, before reporting them to the whole class. Finally, the workshop group highlighted any other examples from the extracts, and discussed the importance of language in reflecting opinions and attitudes. 
Follow-up activity

\section{Evaluation of the workshop}

At the end of the workshop, I asked my students to write a review of the film You've Got Mail for the readers of Film, a popular British movie magazine. My aim here was to further reinforce what students had learned through the workshop, but this time in the written mode. I distributed the guidelines for writing the review, and copies of two sample reviews on another film from the magazine, to familiarize them with its style and format. Students wrote their reviews individually, then peer-checked each other's work, and submitted their revised reviews. I gave feedback on each such assignment, and later invited students to display their reviews in the form of a poster on the school bulletin board. The assignment revealed that students were able to analyze the film critically by making use of many points and opinions discussed in class, as well as other ideas synthesized from a variety of published material. The reviews also revealed an improvement in students' written language ability, with effective use of terminology and creative expression.

In order to evaluate the workshop and the course, I conducted group interviews with students where I asked them to reflect upon the whole process. I then interviewed the students in their workshop groups. Each interview lasted 20-30 minutes, and included students' views on the following questions:

1 Have you found the film course useful? Why? Why not?

2 To what extent has the course helped you to improve your critical thinking skills?

3 To what extent has the course helped you to improve your English?

I made some notes during the interviews, and later analyzed these in four categories that seemed to emerge from the data. The points below indicate common responses raised by students in the group interviews, as well as the four main categories I had assigned to them in my analysis.

a Critical thinking skills The workshop helped us to become active viewers through gaining awareness of how films are constructed, how pieces or details make up a whole, and how they can be deconstructed for a healthier analysis. Questioning, examining aspects of a film, and applying film theories, enhanced our critical thinking skills. Learning to 'read' films can also help us to read other forms of media texts more easily, such as TV commercials, magazines, and newspapers.

b Language skills The film workshop provided us with a motivating context through which we could practice our English by reading, speaking, listening, and writing. We also learned some new vocabulary. We had to read a lot of books in English in order to prepare our workshop, which improved our reading skills, and helped us to learn some new vocabulary. During the workshop itself we had a variety of opportunities to discuss different aspects of the film, which contributed especially to how we express ourselves in English. This was a challenging exercise, though it allowed us to be creative as well.

c Psychological effects The workshop increased our confidence in speaking in front of an audience. After completing the workshop, we felt 
pleased that we could be very creative. Now we know more about the efforts of the people involved in the creation of a film, and therefore appreciate it better. We also believe that we have gained intellectual maturity in the appreciation of the arts.

d Effects of studying films in real life situations After practising how to analyze films, we have started to look at life more critically. A close analysis of characters, events, and values in films helped us to do the same thing in real life. After studying films so closely we can't help but think about what is signified by each object or colour we see in our daily encounters.

\section{Conclusion}

Feature films can be a valuable tool for promoting critical thinking skills, enhancing students' speaking, listening, writing, and reading skills, and increasing their appreciation of arts and artists. Films can help students to think along various dimensions, and thus gain control over media texts instead of simply accepting them superficially. They can also open doors to various disciplines, e.g. cultural studies, media studies, and film studies, which can bring diversity into language classrooms. An important point to keep in mind, however, is that films should be viewed as subject matter in their own right, and be used with a principled approach aiming to improve students' abilities not just in language but also in critical and creative thinking.

In environments where teachers do not have easy access to such technology as television, video players, and the Internet, they can still incorporate films into their English language classrooms by choosing a film on a TV channel, to which all of the students have access, or organizing movie days on which students can go and watch films in a movie theater. However, it is essential to provide guidelines to students, and to set tasks that will allow them to focus on the various different aspects of the film, such as those described earlier.

Final version received October 2001

\section{References}

Allan, M. I985. Teaching English with Video. Avon: Longman.

Baddock, B. 1996. Using Films in the English Class. Hemel Hempstead: Phoenix ELT.

Boggs, J. M. I996. The Art of Watching Films. California: Mayfield.

Branston, G. and R. Stafford. I996. The Media Student's Book. London: Routledge.

Eken, A. N. 2000. 'Integrating media literacy into the English language classroom'.

Small Screen IATEFL Media SIG Newsletter 13/2:

3-5.

Ephron, N. (dir.). I998. You've Got Mail (film).

USA.

Geddes, M. and G. Sturtridge (eds.). I988. Video in the Language Classroom. Oxford: Heinemann.

Hart, A. I991. Understanding the Media. London: Routledge.

58

Ali Nihat Eken
Hill, B. I991. Making the Most of Satellites and Interactive Video. London: Centre for Information on Language Teaching and Research.

Phillips, W. H. I999. Film: An Introduction. London: Bedford/St. Martin's.

Rivers, W. M. (ed.). I994. Interactive Language Teaching. Cambridge: Cambridge University Press.

Stempleski, S. and B. Tomalin. I990. Video in Action. London: Prentice Hall International.

Teasley, A. B. and A. Wilder. I997. Reel Conversations: Reading Films with Young Adults. Portsmouth: Heinemann Boynton/Cook. Tomalin, B. I986. Video, TV and Radio in the English Class. London: Macmillan. 


\section{The author}

Ali Nihat Eken is currently teaching at the Foundations Development Program at Sabanci University in Turkey. He received his MA in English Literature and his PhD in Educational Sciences from Middle East Technical University in
Ankara. His current areas of interest include classroom research, media studies, film analysis, and critical thinking. He has published articles in the areas of film literacy and journal writing, and a self-study book for students studying EFL.

Email: eken@sabanciuniv.edu 